\title{
Perception of Freshmen Students on Statistical Subject in Psychology Study Program
}

\author{
Positive and Negative Perceptions of Statistics
}

\author{
Zerlinda Rezkika Lestari Putri, Meydiisa Utami Tanau \\ Psychology Study Program \\ Universitas Lambung Mangkurat \\ Banjarbaru, Indonesia \\ meydisa_tanau@yahoo.com
}

\begin{abstract}
This study aims to unravel the perception of freshmen students on what are the aspects of perception and the factors that affect perceptions of freshmen students about the statistical subject. In fact, many freshmen students have a slight knowledge of the statistical subject, and that affects the perception of these freshmen students about the statistical subject. There are two types of perception, positive and negative perceptions. This study used a qualitative method with a descriptive approach. The setting was in Psychology Study Program of Lambung Mangkurat University. There were four participants in this study. Data collecting techniques were done by interview and observation. This study used coding for data analysis. Based on the data analysis, it was concluded that at the beginning of the lecture process, there were participants who had positive perceptions and there were participants who had negative perceptions of statistical subjects. However, in the end, all participants have positive perceptions of the statistical subject. This result is due to several factors that influence the perception of freshmen students about statistical subjects
\end{abstract}

Keywords—Perception, statistics, new students

\section{INTRODUCTION}

The number of Indonesian students reaches 4.8 million. When calculated against a population of 19-24 years, the gross enrollment rate is only $18.4 \%$. If calculated based on $19-30$ year income, the gross enrollment rate is only $23 \%$. This number is still below the developed countries. According to Alim Bachri in 2017 the number of 2017 new student quota, Lambung Mangkurat University consists of 5,800 students who will be selected from three selection pathways. Starting from the selection of SNMPTN, SBMPTN and Independent pathway "There was an increase from the previous year which only accommodated 4,800students. Increasing by 1,000 , because the ratio per study program and the number of students and Lambung Mangkurat University are ready to accommodate many students, including in terms of facilities and support," said Alim Bachri. Statistical subject is one of the subjects taught in universities. This subject is a compulsory subject for each study program. The purpose of teaching this subject is for students to understand statistical concepts and procedures and to be able to apply them to analyze the problems to be studied. Such an important subject, but generally students are less interested to learn it. The perception that using statistics requires mathematical skills to be one of the reasons. Statistics and mathematics have formulas in using arithmetic principles. According to Adi, attitude is the process of recognition or the process of using the five senses. Impressions received by individuals are very dependent on all experiences that have been gained through the process of thinking and learning, and it is influenced by factors that originate within the individual [1]. Student perceptions in statistics are a process for students to recognize statistical subjects. Some students recognize with a positive attitude and considered it easy, but there are also those who recognize with a negative attitude and considered it difficult. A student who likes statistical subject tends to be active and eager to learn, while a student who does not like statistical subject will not certainly be eager to learn. Based on the preliminary study conducted by the researchers on October 6, 2017, to freshmen psychology students. They stated that statistic is a difficult subject. At first, they thought that statistical subject would not be difficult, but they heard issues from their seniors saying that statistic is a difficult subject. This opinion changed their initial perception regarding the statistical subject, plus the large number of students taking the statistical class, which made them even have more negative thinking with the statistical subject. This concern is taken into account by the researchers to conduct a study in finding how freshmen students perceptions about the statistical subject in the Psychology Study Program.

In the study of Setiadi asserted that learning styles could increase achievement motivation where the results of the research obtained were more positive perception towards the teacher's teaching style then the higher the student's achievement motivation on mathematics subjects [2]. According to the research of Hermawati, the learning process in learning must be supported by functions, one of which is a sympathetic and attractive, flexible, wise and simple attitude in acting. The lecturer must be sympathetic and attractive in explaining the subject matter to be developed by students where this will surely lead to positive perceptions. These things are that make people think positively in the statistical subject, teaching styles and personal ability[3]. Through this study, the researchers want to know the first student's perception of the subject of statistics, so that it can be followed up by knowing student motivation and student learning outcomes. This study can provide some suggestions to the lecturers about the teaching style of lecturers and the personal abilities of the lecturers to maintain positive perceptions of the students. 


\section{METHOD}

\section{A. Instrument}

This study eployed a qualitative method with a descriptive approach. Data collecting techniques in this study were interview and observation. This study used coding for data analysis. The first step was to do open coding, which is to provide codes on all interview data that has been transformed into verbatim. Furthermore, doing axial coding to sorting through information on open coding that is considered related to research and then provides new categories of information that has been sorted. The last step taken in the process of data analysis was selective coding, which is sorting out the categories that have been made before in accordance with the objectives of the researchers related to the perceptions of new students in the statistical subject.

\section{B. Participant}

The participants of this study were four new students of the Lambung Mangkurat University on Psychology Study Program. The interview was conducted at the participants' residence in Banjarbaru. The first participant was $\mathrm{S}$, an 18year-old male. The second participant was $\mathrm{F}$, an 18-year-old female. The third participant was $\mathrm{H}$, a female, 21 years old. And the fourth participant named S was a 19-year-old male.

\section{RESUlTS AND DiscUSSION}

The interview on participant 1 was held on Friday, October 13, 2017, at 4:00 p.m. The first subject named S. S is an 18year-old male. $\mathrm{S}$ is a new student in the Psychology Study Program at Lambung Mangkurat University in Banjarbaru. S has extensive knowledge of the usefulness of statistics, which he acquired after several times taking the statistical subject. S' perception on the statistical subject is fairly positive. S said his feeling when he attended the statistical subject was same like studying any other subject. It is because, on the high school, he majored in science, and the subject that the participant liked was Mathematics. So, the participant does not have a negative perception on the statistical subject. Another reason why the participant like the statistical subject is because the lecturer who teaches this subject is the mother of a participant friend. The participant claimed that it had a subjective influence on his perception of the statistical subject. Finally, the participant said the importance of the statistical subject in research and data collection, which makes the subject feels the statistical subject is essential.

The interview on participant 2 was held on Friday 13 October 2017 at 5.45 p.m. The second participant with the initials $\mathrm{F}$ is an 18-year-old female. At first, the participant claimed that she does not like the statistical subject because the participant does not really good at calculating. Moreover, the participant heard rumors about the statistical subject taught by a "killer" lecturer. But, the participant's perception changed after a couple of attendances to the statistical class. The thing that changed her perception of the statistical subject was the lecturer teaching the current statistical subject. The participant said that the lecturer is good at teaching. However, there is something that inhibits the participant's focus in class. It is the temperature factor because the air conditioner in the classroom is not on. Nevertheless, so far, the participant claimed to be still able to attend statistic class to date.

The interview on participant 3 was conducted on Saturday 14 October 2017 at 4:05 p.m. The third participant with the initials $\mathrm{H}$ is a 21 -year-old female. $\mathrm{H}$ has a fairly negative initial perception in the statistical subject because she hates counting. Moreover, the participant majored in social studies on high school, and the subject that the participant did not like the most was mathematics. It has further strengthened the negative perception of the participant on the statistical subject. Coupled with the doctrines of her previous friends who said that statistical subject is very difficult. After a couple of attendances to statistical class, her perception gradually changed to become more positive. It is because the participant's knowledge increases after several times attending statistical class. Willingness of the participant to study the statistical subject encourages her to be active in asking questions with friends about things she did not know when studying statistics. Other driving factors are the lecturers who according to the participant are comfortable in teaching because the lecturer repeats the subject matter until students understand the lesson for that day. The teaching method performed by the lecturer also fits the participant class atmosphere. The participant admitted that after several times attending the statistical subject, the statistical subject is not too difficult anymore. In addition, the participant's perception that was very negative towards the statistical subject has now begun to change in a positive direction.

The interview on participant 4 was conducted on Saturday, October 14, 2017, at 8.15 p.m. The fourth participant with the initials $\mathrm{P}$ is a 19-year-old male. Based on the conducted interview, before attending the statistical class, the participant did not know much about this subject. He only knew that the statistical subject would be useful to compile the final assignment. Even so, the participant's perception of the statistical subject was fairly positive, even though he had heard rumors about this subject. It is due to the curiosity of the participant to the statistical subject. However, there are other factors that disrupt the concentration of the participant when studying statistics such as friends around the participant, where the participant is sitting, the room temperature is quite hot because the air conditioner isn't on, and feeling bored and hungry. But the participant tried to maintain his focus by rebuking his noisy friend and paying attention to the lecturer's explanation. One of the factors that makes the participant still has a positive perception in the statistical subject is because of the lecturer. In addition, the participant is also not affected by rumors regarding the statistical subject, because the participant feels that he must see what going on first. Besides that, the participant can understand the explanation from the lecturer. The participant can also understand the tasks given by the statistics lecturer. Therefore, the initial perception of the participant before and after attending the statistical subject remains the same, positive.

In this case, the four participants have different perceptions before attending the statistical class. Participant $\mathrm{S}$ and participant $\mathrm{P}$ had positive perceptions before attending statistical class, and participant $F$ and participant $H$ had negative perceptions before attending statistical class. At the 
end, all participants have a positive perception after attending the statistical class. Perception is the interpretation of an object, event or information that is based on the life experience of someone who does the interpretation. What someone feels can be substantially different from objective reality [4]. According to Irwanto, after individuals interact with the perceived objects, the perception results can be divided into two, positive perceptions and negative perceptions [5]. There are two factors that influence perception, functional factors and structural factors [6]. Functional factors are factors that come from needs, past experiences and other things that include what we call personal factors. In this case, the functional factor of participant $\mathrm{S}$ was his past experience in high school which majored in science and liked mathematics so that $\mathrm{S}$ had a positive perception in the statistical subject. Whereas in participants $\mathrm{F}$ and $\mathrm{H}$ have unpleasant experiences related to calculations, so they have negative perceptions before attending statistical subject. But in subject $\mathrm{P}$, he had a positive perception before attending statistical subject even though functional factors for the past experience of the participant did not like mathematics.

There are two perception aspects according to McDowell \& Newell, cognition aspects and affective aspects [7]. Aspects of cognition are aspects that involve ways of thinking, recognizing, and interpreting a stimulus received by the five senses, experience or that has been seen in everyday life. Hurlock adds that cognitive aspects are based on the concept of information, this cognitive aspect is also based on personal experience and what is learned [8]. Participants S, F, H, and P previously had little knowledge about statistical subjects, but after attending statistical class, their knowledge grew more and more about the statistical subject so that eventually all participants had a positive perception on the statistical subject. Meanwhile, the affective aspects are aspects that build cognitive aspects. This affective aspect includes the way an individual feels, expresses emotions towards a stimulus based on the values in them which then influence their perception. In this case, participant $\mathrm{S}$ was pleased with the statistical class and was pleased with the lecturer who taught this subject so that made $\mathrm{S}$ have a positive perception in the statistical subject. In participants $\mathrm{F}$ and $\mathrm{H}$, before attending the statistical subject they felt fear and hate with matters related to calculations so that made them have negative perceptions, but after attending the statistical class they felt they could still attend statistical subject and like the lecturers who taught this subject so that they make their final perception positive. In subject $\mathrm{P}$, before attending the statistical class, the participant felt normal so that it made the participant's perception remained positive before attending the statistical subject and after attending the statistical subject the participant's feelings remained the same so that it did not change the perception of participant $P$.

\section{CONCLUSION}

Based on the cases that occur from all participants, it can be concluded that their negative and positive perceptions are caused by the functional factors and structural factors. Moreover, there are also several aspects that affect the perception of the participants on the statistical subject, including aspects of cognition and affection. This study also shows that negative perceptions of students can be positive because of the interesting teaching style of statistical subject lecturers and the personalities that the lecturers had. Therefore, it is important for statistical lecturers to improve the teaching style of their lecturing and improve their personal abilities in order to produce positive perceptions of students about statistics.

\section{ACKNOWLEDGMENT}

I would like to thank each participant for their help in doing this research, carried out in the Psychology Study Program, University of Lambung Mangkurat, Banjarbaru.

\section{REFERENCES}

[1] P. Adi, "Pengaruh Metode Pembelajaran dan Persepsi Siswa pada Kompetensi Sosial Guru terhadap Kompetensi Belajar Matematika Siswa," Ph.D. dissertation, Dept. PGRI. Ind., Indraprasta Univ., Jakarta, 2010 .

[2] B.A. Setiadi and I. Setyawan, "Hubungan Antara Persepsi Terhadap Gaya Mengajar Dengan Motivasi Berprestasi Pada Mata Pelajaran Matematika Di SMA Negeri 5 Semarang," Empati, vol. 4, no. 2, 2013.

[3] Hermawari, "Hubungan Persepsi Mahasiswa Tentang Kepribadian dan Kemampuan Dosen Dalam Mengajar dengan Motivasi Belajar Mahasiswa Akademi Kebidanan Kutai Husada Tenggarong," .D. dissertation, Dept. Medical. Ind., Sebelas Maret Univ., Surakarta, 2010.

[4] S.P. Robbins and Jacob, Perilaku organisasi, Jakarta: Salemba Empat, 2002.

[5] I. Irwanto, Psikologi Umum, Jakarta: PT. Prenhallindo, 2002.

[6] J. Rakhmat, Psikologi komunikasi, Bandung : Remaja Rosdakarya, 2003.

[7] I. McDowell, and C. Newell, Measuring Health: A Guide to Rating Scales and Questionnaires. 2nd ed. New York: Oxford University Press, 1996.

[8] E. B. Hurlock, Psikologi Perkembangan: Suatu Pendekatan Sepanjang Ruang Kehidupan, Jakarta: Erlangga, 1999. 